\title{
Community-based Ecotourism Model for Development UNESCO Global Geopark: A Case Study of UGG Batur Bali, Ciletuh-Palabuhanratu West Java, and Toba Caldera North Sumatra
}

\author{
Orpha Jane ${ }^{1 *}$, Gandhi Pawitan ${ }^{2}$ \\ ${ }^{1}$ Master of Business Administration Program, Faculty of Social and Political Science, Parahyangan Catholic University \\ ${ }^{2}$ Master of Social Science Program, Faculty of Social and Political Science, Parahyangan Catholic University
}

\begin{abstract}
Geopark or the established UNESCO Global Geopark (UGG), such as Toba Caldera, Batur, or Ciletuh, in fact, will stimulate local economic development, such as through ecotourism, by monetizing the potential of their geo-diversity, bio-diversity, and local culture. It is argued that the ecotourism model that involving the local community has great potential in supporting the success of Geopark's sustainability. This study contributes as the best practice and guidance in managing the current UGG or developing the next UGG. Hence, this study aims to explore and describe the implementation of Geopark management following a community-based ecotourism model. Three cases study were carried out in UGG Batur, Ciletuh, and Toba Caldera. Some aspects were studied, including key stakeholders and their roles, mapping community involvement, and implementation of the CBE in managing the UGG. Focus group discussions were done with resource persons from five main sectors, namely academics, government, community, entrepreneurs, and the media. The results show that in most cases, the Geopark sites belong to the community or managed by the community, which is considered as a good condition for stimulating the CBE model. Applying the CBE model effectively requires key actors in the community with soft and hard skill competencies.
\end{abstract}

Keywords: Batur Lake Bali, Ciletuh-Palabuhanratu West Java, Community-based ecotourism, Community involvement, Geopark, Toba Caldera North Sumatera.

\section{INTRODUCTION}

Community-based ecotourism (CBE) has become a significant approach in protecting the environment while also promoting tourism [1]. It is because ecotourism will boost the conservation program of the specific area [2], such as for the geological heritage. At the same time, the local community involvement will create a positive impact for the improvement of the economic benefits for the community $[3,4]$. Jones and Scheyvens argue that, particularly in developing countries, CBE is a means to reconcile environment conservation (wildlife in Jones's term) with the economic development in a rural area $[5,6]$. Meanwhile, the tourism industry is considered a key contributor to economic development, as reported by the WTTC at the Annual Economic Report 2017: the role of travel and tourism in economic development is undoubted. Its role also including in creating jobs for many people throughout the world. More specifically, travel and tourism have a direct contribution of US\$2.3 million to economic development and 109 million jobs. Meanwhile, the indirect and the induced impact on the global economy was US\$7.6 trillion and around 292

*Correspondence address:

Orpha Jane

Email : jane@unpar.ac.id

Address : Jl. Ciumbuleuit No. 94, Bandung 40141 million jobs. Those are equal to $10.2 \%$ of world's GDP and 1 in 10 of all jobs.

As a part of the tourism industry, ecotourism also grows significantly and becomes a relevant sector [7]. It is because the demand for wildlife or natural attraction has become more popular among tourists in the world. It is also a case for Indonesian tourist attractions. The following figure is drawn from the data published by Statistic Center in 2017, showing a percentage of business entities by the tourism attraction sectors. Water and nature tourism show the highest percentage, which indicates the highest demand in these sectors. Figure 1 indicates that water and nature tourism shows the largest business appeal and is followed by artificial tourism or man-made attraction, such as a dreamland. Meanwhile, Figure 2 shows a mapping of provinces that have different appealing characteristics. The first cluster shows provinces with characteristics of high attraction in Nature and culture tourism. The second cluster shows provinces with high water and natural attraction, and the third cluster shows a combination of amusement recreational park, nature, and water tourism.

The figures show that nature, water, and culture tourism have attracted business, involved either government or individual. Recently, community involvement has been considered growing in this tourism, which develops ecotourism [8]. 


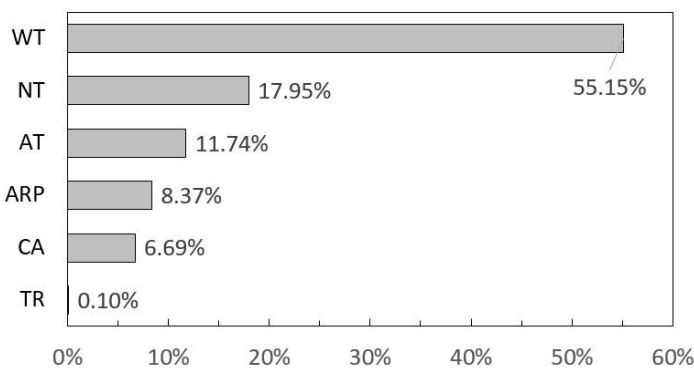

Figure 1. Percentage of business in by tourism sector (WT=water tourism, NT=nature tourism, $\mathrm{AT}=$ artificial tourism, $\mathrm{ARP}=$ amusement and recreation parks, $C A=$ culture attraction, and $\mathrm{TR}=$ tourism region) (Source: Statistic Center, 2017)

One of the ecotourism types is a tourism attraction from the Geopark, which offers the beauty of the unified geo-diversity, bio-diversity, and local culture in geographical heritage areas, commonly a volcano's eruption. It is primarily known as UNESCO Global Geopark (UGG). It promotes sites of international geological value and is the basis of local, sustainable development (as explained in UNESCO official website, 2017). The UNESCO Global Geopark - UGG (2017) is an associate heritage geographical area that has a tremendous value and is managed to protect its value. It is not only to protect the heritage but also to educate society and sustain it. More specifically, it is an integration of geological, natural, and cultural heritage. The UGG unifies it to enhance the benefits of this heritage to conserve it.
Since the UGG is inherent in the area surrounding the local community, the community-based approach is the best way to encourage the development of UGG. More specifically, with the collaboration between the stakeholders and all relevant parties, including the regional government. In other words, UNESCO is stimulating a community-based approach while promoting the geological heritage area, and at the same time, also developing ecotourism.

This research proposes that in developing the UGG, the community-based approach is the best approach that can use by the local government. It is because the geopark is located within the community, which has a connection among people, nature, culture, and economics. This connectivity assures understanding we had to know in-depth knowledge and precisely all the three aspects of UGG: geo-diversity, bio-diversity, and local culture. Hence at the same time, developing UGG will also encourage the development of ecotourism.

Moreover, this research uses three UGG that is (1) Batur Lake, located in Bali; (2) CiletuhPalabuhanratu, located in Sukabumi, West Java; and (3) the new one is Toba Caldera in North Sumatra. Batur Lake is one of the popular international tourist destinations in Indonesia, specifically in Bali, which also a UNESCO Global Geopark. The area is a geological heritage that is coming from an eruption of Mount Batur.

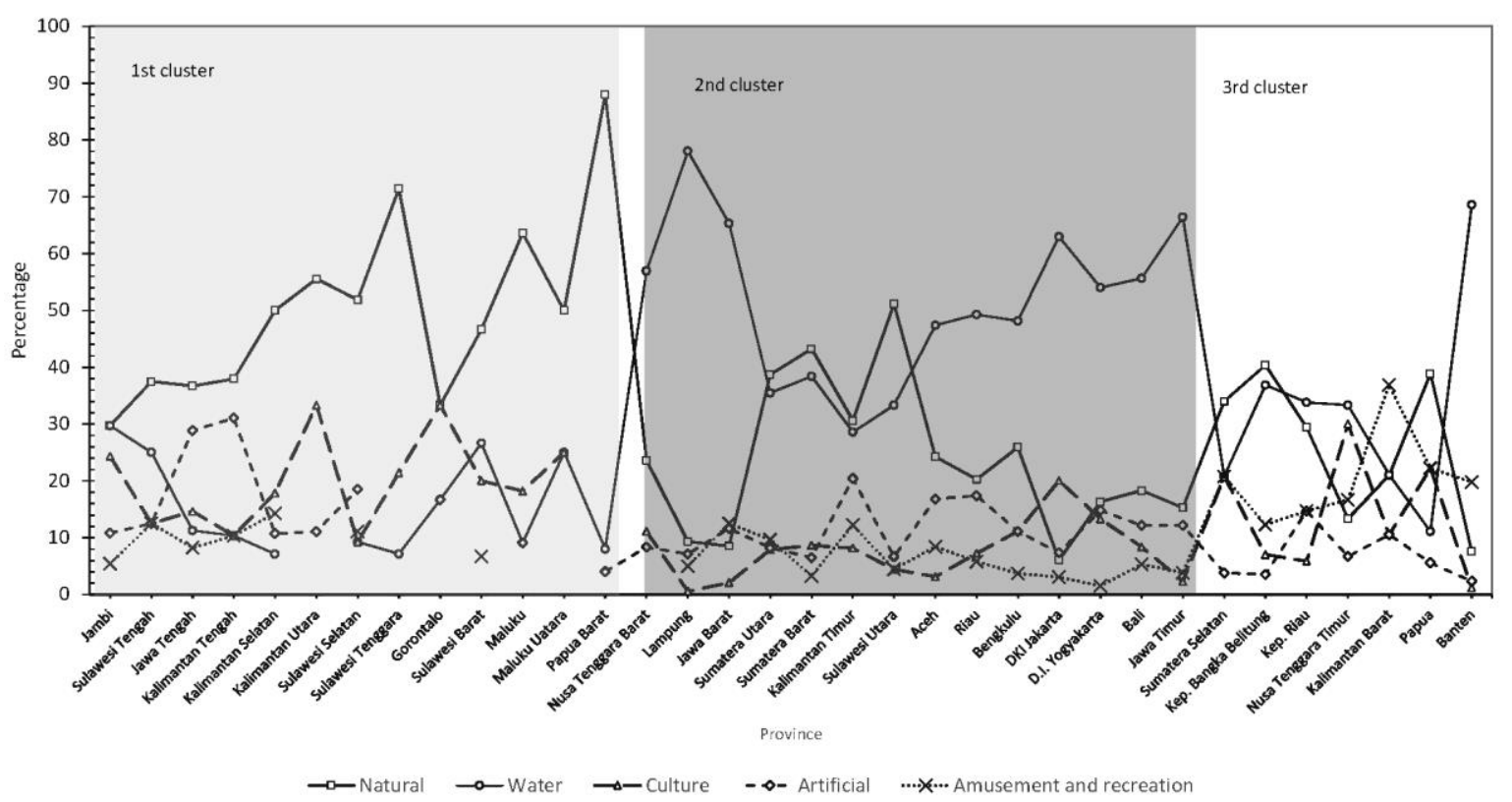

Figure 2. Percentage of business by tourism sector and provice (Source: Statictic Center, 2017) 
As mention on the website, Batur UNESCO Global Geopark includes two volcanic calderas and presents a complete volcanic landscape with caldera walls, cones and craters, geothermal phenomena (fumaroles, hot springs), a lake, lava flows, pyroclastic flows, and tephra. The phenomenon of double-calderas with a crescentshaped volcanic lake ( $7 \mathrm{~km}$ long, $1.5 \mathrm{~km}$ wide) and located 1,031 $\mathrm{m}$ a.s.l. was called the most beautiful caldera in the world. The uniqueness of the area's geology array is the volcanic origin, endemic flora and fauna, and aboriginal culture motivated by the Balinese Hindu religion. These are a perfect combination of different heritages of the Earth.

Meanwhile, Ciletuh-Palabuhanratu is the Unesco Global Geopark that contains eleven geological sites and is grouped into three geo areas, namely Cisolok, Jampang, and Ciletuh. The location has a 126,100 ha area or $1,261 \mathrm{~km}^{2}$. Besides the UGG, some tourist attractions beyond this area are Cibanteng, Tangkubanparahu, Sukawayana Nature Reserve, Cikepuh Wildlife Reserve, Sukawayana Nature Park. Also, there are some facilities like an integrated military training area managed by KOSTRAD, a turtle conservation area in Pangumbahan, an air force exercise area on the Ujunggenteng Cave, Regional shrimp aquaculture in Mandrajaya and Ujunggenteng, and batik village in Purwasedar $[9,10]$.

Toba Caldera (TC), as a new UGG in Indonesia, is the most magnificent caldera in the world and has a unique geological heritage. The landscape of TC is the result of a volcanic massive explosive volcanic eruption that formed the caldera. The basin of the caldera led with water forming a lake which occupies $90 \times 30 \mathrm{~km}^{2}$. In the middle of the lake is an island called Samosir Island. The caldera wall, which is commonly steep slopes, becomes a watershed. The surface elevation is about 2,000 $\mathrm{m}$ a.s.l. There are 15 geosites surrounding the TC with four geo areas, such as Haranggaol, Porsea, Sibandang, and Samosir.

The topography of the area around the lake is undulated hills (43\%), mountains (30\%), and plain (27\%). The area of TC Geo area is estimated to have a population of 263.978 distributed in seven regencies, belongs to the North Sumatra Province. Settlements occupy the plains, where they practice their daily activities. This area is locally inhabited by Batak Toba, Simalungun, Karo, and Pakpak ethnics. We can argue that the development of UGG is the practice of sustainable tourism, which contains three aspects: social justice, economic development, and environmental integrity. It means that UGG should have an impact on the wealth of the local community without broken natural resources. In that context, it is clear that UGG is in line with the development of sustainable tourism that maintains the balance of ecology and searches for sustain the bio-diversity, respect for local value, and at the same time, gives tolerance and multi-local understanding.

Therefore, the development of UGG has a critical agenda, which will leverage the ecotourism in the UGG area, and achieve the UNESCO'S agenda toward UGG that is a holistic concept of protection, education, and sustainable development. Also, it will leverage the local economy by enhancing the participation of the community in the development of tourism, specifically ecotourism. In the case of Toba Caldera, it is more specifically to bring back the popularity of Lake Toba. Since there is a declining trend of the number of visitors local and international comes to Lake Toba recently.

The objective of the study is to explore and describe the implementation of geopark management following community-based ecotourism. This objective is achieved by investigating the following situation. First, we explored the community involvement in managing and developing UGG Batur, CiletuhPalabuhanratu, and Tobal Caldera. Second, we described and identified the key stakeholder and their role in developing UGG. Third, we described the implementation of the community-based ecotourism model in the UGG.

\section{Ecotourism Review}

The development of park tourism and ecotourism has been considered an important effort in biodiversity conservation. The effort has connected the community, environment, and tourism. Some good practices have been exposed widely, such as wildlife tourism around Sariska Tiger Reserve India [11], and Hainan, China [8]. A direct benefit is not only perceived by the people around the tourism areas but also by other actors, including business owners and the government. Sekhar stated that among direct economic benefit, park and ecotourism also induced indirect benefit, such in the environment conservation, community development, and national pride $[4,11,12]$.

Since the last two decades, ecotourism has become one of the major topics in the tourism industry $[2,4,5,6,7,13]$. More specifically, because 
its focus is on the undisturbed natural area [7], wildlife conservation [5], biodiversity conservation [4], remote, natural and exotic environments [6] makes a specific segment of tourist give attention to this attraction. Stronza and Gordillo argued that ecotourism sustains the rural livelihoods, catalyzes new development, renews cultural pride, empowers local peoples, and protects biodiversity [2].

Wood stated that the United Nations designated 2002 as the International Year of Ecotourism [13]. The Commission on Sustainable Development (CSD) also mandated the United Nations Environment Programme (UNEP) and the World Tourism Organization to carry out activities for the year because the potentials of ecotourism are to benefit society as well as a burden if it is not well organized [13]. The goals of this program are to review the lessons learned in implementing ecotourism, to identify and promote forms of ecotourism that lead to the protection of critically endangered ecosystems. Meanwhile, it also shared the benefits of the activity.

Moreover, Wood argued ecotourism has a specific offering in the conservation program and becomes a growing niche market within the more massive travel industry [13]. In addition, ecotourism becomes an essential sustainable development tool. It is known that ecotourism's annual sales up to billions of dollars, so this specific tourism offering has the potency to take advantage of the tourism market overall. Also, ecotourism offers a different attraction than other segments of the tourism industry. More specifically, ecotourism is a tourist attraction as a result of sustainable development, such as conserving natural areas, educating visitors about sustainability, and benefiting local people.

Ecotourism is about aligning among environmental resources, community development, and tourism [14]. They argue the three critical aspects in the development of ecotourism, namely environmental, economic, and social sustainability. Hence, it is believed that ecotourism development invites further financial and political support.

Similarly, The International Ecotourism Society (TIES) in 2019 also concludes explicitly that the principle of ecotourism is uniting the conservatives, communities, and sustainable travel. It means that besides the natural aspects, the community has a significant role in developing tourist potency. It is in line with this research proposal that the tourism potency, including the geopark as one of the forms of ecotourism, should be developed by the local community.

Because the relation of ecotourism with society is very close, as suggested by scholars, that ecotourism supports sustainability and economic development, it is widely recognized that the role of community is central to the development of ecotourism. As defined by TIES, ecotourism is responsible travel to natural areas that conserves the environment and improves the well-being of local people. From this definition, it is clear that the development of ecotourism will be more productive with the community-based approach. Specifically, Kiss [4] mentioned that:

"The attraction of community-based ecotourism is the prospect of linking conservation and local livelihoods, preserving biodiversity while simultaneously reducing rural poverty, and achieving both objectives on a sustainable (self-financing) basis."

The community-based approach to ecotourism has two main benefits. It was to promote both the quality of life of people and the conservation of resources [6]. In this context, we can say that from a development perspective, which considers social, environmental, and economic goals, the approach of responsible community-based ecotourism can 'meet the needs of the host population in terms of improved living standards both in the short and long term [15]. Besides, there is another perspective that somewhat differs from an environmental perspective. The perspective is high-light the ecotourism based on nature tourism that is sustainably managed, includes environmental education and supports conservation $[6,16]$.

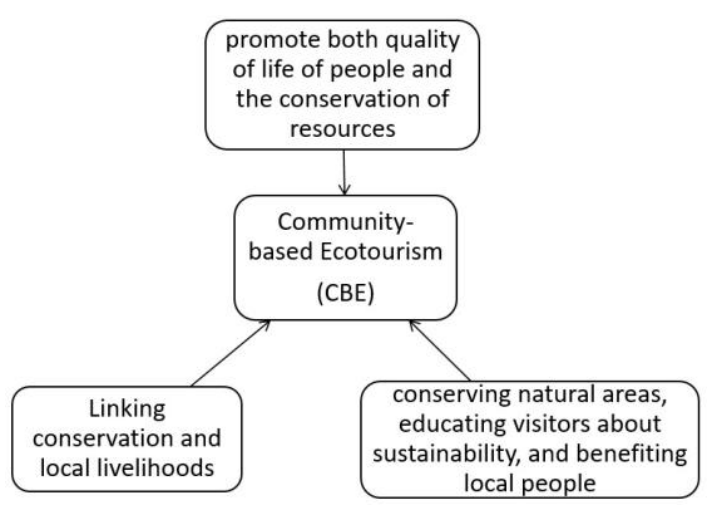

Figure 3. The theoretical framework of community-based ecotourism

From those perspectives, we can summarize in the framework, as shown in Figure 3. The 
theoretical framework of Community-Based Ecotourism (CBE) developed as a summary from the approach of scholars. From the framework, we hypothesize that CBE has two major aspects, those are (1) promote quality of life by benefiting the local economy and (2) conserving natural resources.

\section{Community-Based Ecotourism From The Perspective of UGG}

In addition to these CBE, UNESCO gives a different approach to manage the attraction that related to somehow what we concern as an object or attraction of ecotourism, among others, biodiversity and local culture. UNESCO, more specifically Global Geopark, offers a new perspective of organizing and managing the environment as a tourism attraction, which is a geological heritage area.

UNESCO Global Geopark is a single, unified geographical area where sites and landscapes of international geological significance are managed with a holistic concept of protection, education, and sustainable development. A UNESCO Global Geopark uses its geological heritage, in connection with all other aspects of the area's natural and cultural heritage, to enhance awareness and understanding of critical issues facing society, such as using our earth's resources sustainably, mitigating the effects of climate change and reducing natural disasters-related risks. By raising awareness of the importance of the area's geological heritage in history and society today, UNESCO Global Geopark gives local people a sense of pride in their region and strengthens their identification with the area. The creation of innovative local enterprises, new jobs, and high-quality training courses is stimulated as new sources of revenue are generated through geo-tourism, while the geological resources of the area are protected ${ }^{1}$.

\begin{abstract}
A Bottom-Up Approach
UNESCO Global Geopark is using a bottom-up approach in developing the geopark by empowering local communities and give them the opportunity. More specifically, the approach aims to develop a cohesive partnership to get the common goal of promoting the area's significant geological feature or outstanding geological beauty. By this approach, it is hoped that the process will involve all relevant local and regional stakeholders and authorities in the area (e.g., landowners, community groups, tourism
\end{abstract}

\footnotetext{
${ }^{1}$ http://www.unesco.org/
}

providers, indigenous people, and local organizations). This process also requires all the stakeholders to develop a comprehensive strategy to meet all of the communities' goals while showcasing and protecting the area's geological heritage. The stakeholders are a firm commitment by the local communities, reliable local multiple partnerships with long-term public and political support.

To become one of UNESCO Global Geopark, it must demonstrate the geological heritage of international significance. It is because the purpose of a UNESCO Global Geopark is to explore, develop, and celebrate the links between that geological heritage and all other aspects of the area's natural, cultural and intangible heritages. It is about reconnecting human society at all levels to the planet we all call home and celebrating how our planet and its 4,600 million years long history have shaped every aspect of our lives and our societies.

From those descriptions, we can summarize that UGG support and, at the same time, enhance community-based ecotourism. It is because the attraction of the UGG is closely related to the focus of ecotourism's object and attraction. Furthermore, also, the UGG approach to explore and promote the geological heritage area.

\section{MATERIAL AND METHOD}

A qualitative approach is applied in collecting and analyzing data, which includes triangulation of findings. A case study and observation method is done, with some key informants were interviewed. Following Yin [17], the case study is defined as an empirical inquiry that investigates a contemporary phenomenon within its real-life context, when the boundaries between phenomenon and context are not evident and in which multiple sources of evidence are used.

In this study, the phenomenon is the implementation of community-based ecotourism in developing Unesco Global Geopark, within the real-life context of Toba Caldera region, including their nature, community, and system. The selected cases are chosen to figure the phenomenon and the preparation stages of developing the UGG, including:

a) UNESCO Global Geopark Batur Lake

b) UNESCO Global Geopark CiletuhPalabuhanratu

c) UNESCO Global Geopark Toba Caldera

The three locations of UGG were selected since some early information of community 
involvement in developing the UGG is significant. Hence, those cases are relevant and valid in achieving the research objective.

We explored the three regions' development and the design of some pre-requisite of UNESCO Global Geopark and the role of the community involved in this process. The unit analysis for each case is defined as a process in the following aspect.

a) The management of UNESCO Global Geopark Batur Lake

b) The preparation team of UNESCO Global Geopark Ciletuh-Palabuhanratu from UPI (Universitas Pendidikan Indonesia-Bandung)

c) The management of UNESCO Global Geopark Toba Caldera

In achieving those data collection, some informants are selected as key informants, selected from each region. The key informants include:

a) Batur Lake: Manager of UNESCO Global Geopark, Head of The Tourism Office in Kintamani Bali

b) Ciletuh-Palabuhanratu: Development team of UGG

c) Toba Caldera: Manager of UNESCO Global Geopark, Head of Tourism Office Samosir, Head of Association of Hotels and Tourism Samosir

\section{Data Collection and Data Analysis}

Primary data collection was done by some depth interviews and focus group discussion, and also field observations. Meanwhile, secondary data was collected from their websites and published documents.

Descriptive analytics was done to disclose information and pattern from the cases. Thick description and examination of the process were also performed from some facts revealed by the informant.

\section{RESULT AND DISCUSSION}

The development of UNESCO Global Geopark (UGG) is essential, not only as a strategic effort in the conservation of nature but also as a national icon. Hence at that time, it will drive the economy, improve social life and environmental sustainability. According to UNESCO, Indonesia currently has four recognized geopark, which are Batur UNESCO Global Geopark, Ciletuh Palabuhanratu aspiring UNESCO Global Geopark, Gunung Sewu UNESCO Global Geopark, and Rinjani-Lombok UNESCO Global Geopark. The next global geopark will be announced by the UNESCO is Toba Caldera.

This study offered an argument that the community-based ecotourism (CBE) model is the fit approach for the development of the UGG. The cases are studied and discussed from the development of the Batur Geopark Bali, CiletuhPalabuhanratu Geopark Sukabumi, and Toba Caldera Geopark North Sumatera. Following the proposition of this research, UGG is built within the community that promotes the protection and sustainability of the environment. At the same time, it drives the local economy and improves the social life of the community, which is the focus of ecotourism.

The case study research approach is employed by arranging and identifying the development process of the Batur Geopark, Ciletuh-Palabuhanratu Geopark, and Toba Caldera Geopark. The approach examines the roles of some key actors in the CBE, namely the local community, government, and academician/ scientist. By doing this, we proposed the community-based ecotourism model as a road map for the conservation of human ecology. This part will be divided into two sections, the description of the development of the three UGG Batur, Ciletuh-Palabuhanratu, and Toba Caldera. Furthermore, the second is the discussion about the model.

\section{Batur UNESCO Global Geopark}

The Batur UNESCO Global Geopark is located in the district of Kintamani, Bangli Regency, Bali Province. There are fifteen villages surround the area, which is primarily based on agriculture and tourism as their economic backbone. Their featured products are including sweet orange and coffee, wooden and bamboo carving. The Batur UGG turns into an object for nature conservation, education, and economic growth, and sustainability through tourism.

The stages of Batur become one of UGG in the world, according to DKS, Head of Batur UGG and DMA, Head of Geopark Museum, are discussed and summarized in Figure 4 below. The development of the Batur UGG, start from the initial setup until considered as UGG, involves six stages. The process involved some key actors from the local community, local government, business sectors, and scientists or academicians.

The figure indicated that the development process initially started with the capacity building for key actors. Some key actors were identified and invited to be involved in the development 
process, namely local people, local tourism authority, tourism business people, and UNESCO. The capacity building has an objective to enhance the knowledge about the UGG so that all the key actors are ready to participate in the development process. Furthermore, the goal of the capacity-building program is to get an initiative awareness from the local key actors, particularly from local people in the prospective area, so they are ready and take part in the development of the UGG. This capacity-building program essential because it is needed to prepare the dossier as requested by UNESCO, mainly because one of the UGG approaches is a bottom-up approach. The involvement of the local tourism authority becomes a central driver, which is called Kantor Dinas Pariwisata (Office of Tourism Authority) of Kintamani District.

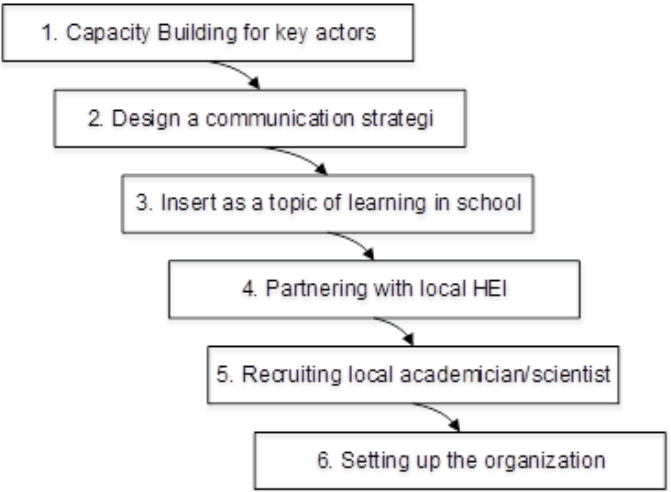

Figure 4. The Development Stages of Batur UGG

The authority office has the primary role in this process, especially in terms of managing the development of ecotourism as a consequence of UGG. Hence, the authority office builds and manages the process by involving local people in several ways, such as building local community group support called Pokdarwis (Tourism Awareness Group), a group of local people that aware of the tourism potency, and support the government specifically Office of Tourism Authority. There are 15 groups of Pokdarwis in the UGG zone. Each of the Pokdarwis group should create a specific program in every village called Gerbangsigot (local teamwork - gotong royong) that pursues to identify the issues or problems of tourism and how to solve it. The group has financial support from the local government.

Meanwhile, there is a program for tourism business people, which focuses on a marketing program for a fostering tourism village to have professional tourism management and develop a group called Fordewi that is a forum for tourism village. It is not only local people and business people that have a strategic role. UNESCO itself need to participate in branding for the global market and the empowering with specific workshop.

The second stage is the design of a communication strategy with a focus not only on society but also (and this is the major one) on local people to have their attention and involvement in the program. Because the UGG is not conventional tourism, it is why we need to communicate intensively. Also, the communication can help the preparation for the UGG's dossier that is the identification geo feature and geo-cultural.

The third stage is the involvement of UGG in the curriculum of a local school. This stage is essential because the purpose of a UNESCO Global Geopark is to explore, develop and celebrate the links between that geological heritage and all other aspects of the area's natural, cultural and intangible heritages. Those purposes should be known by everybody, especially local people, more specifically students. For students, it is not only a piece of knowledge but also to give them a sense of belonging to the geological heritage and the understanding that they have a responsibility to keep and maintain it.

Besides spreading the knowledge through the school's curriculum, the fourth stage is building a partnership or collaboration with a local university and expecting their contribution as a geological and environmental scientist or advisor of the UGG. This partnership is essential because local scientists will support the process and will give scientific advice.

The last stage is setting up the organization to manage the daily activities of the geopark. It is a crucial aspect because geopark should be las long, and it is the mission to preserving the geology heritage and all surrounding it, so we need a specific institution. Besides having the responsibility to manage the geopark daily, this institution also has to manage and maintain the official website as one of the critical tools for educating and socializing the benefit of UGG. Figure 5 shows the Website of UGG Batur Lake.

As a tourism spot, the Batur UGG also develops the museum as a place to give knowledge and understanding about the mission of geopark to people, including students, society, and people from all over the world. The pictures of the museum of UGG Batur shown in Figure 6. Visitors are entertained by a beautiful and 
comfortable surrounding. Site information is also provided, either around the museum and the lake (Fig. 7).

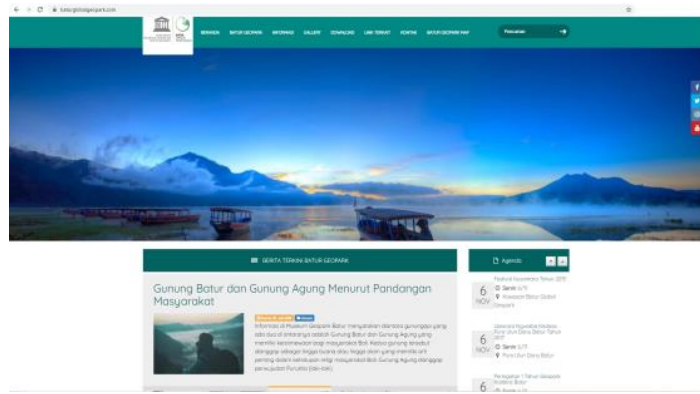

Figure 5. Website of Batur UGG (baturglobalgeopark.com)

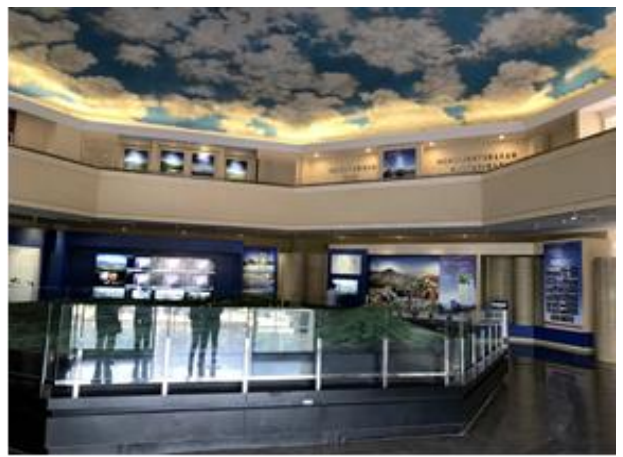

Figure 6. Museum of Batur UGG (Personal documentation, 2019)

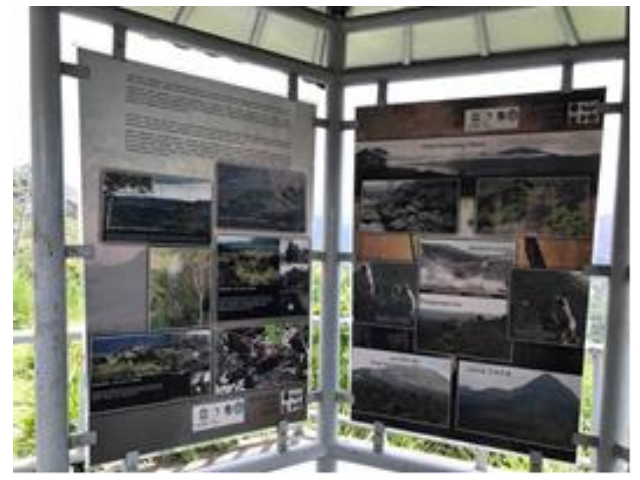

Figure 7. Information's board of Batur UGG (Personal documentation, 2019)

\section{Ciletuh-Palabuhanratu UNESCO Global Geopark}

Ciletuh-Palabuhanratu UNESCO Geopark consists of three main geographical areas, namely Cisolok, Jampang and CiletuhPalabuhanratu. The UGG occupied the area of 126, $100 \mathrm{Ha}$, including 74 villages and eight municipals. The development of the CiletuhPalabuhanraturatu UGG implements the official UGG approach, which is the bottom-up approach. Meanwhile, the authors use the Penta helix approach for exploring and discussing the geographical - biological, and Cultural of CiletuhPalabuhanratu UGG. The Penta helix approach identified five key actors, such as:
1. Academics, representing elements of the university, colleges, or research institutions

2. Community represents the people who live and stay in the region

3. Government includes representatives of the government from the lowest level in the village until the governor, as well as the central government institutions under the ministry

4. Entrepreneur representing the state-owned and private sector

5. Mass media

Those five key actors hold the same vision and mission in conserving natural resources and improve the economy of the surrounding communities. Ciletuh-Palabuhanratu Geopark's development program is the integration of those five key actors. It means including local communities, the local government of Sukabumi Regency, West Java provincial government, Balai Besar Konservasi Sumber Daya Air - BBKSDA Jawa Barat, Universitas Padjadjaran, Geological Agency, and Biofarma. They are representing the private sector and other institutions in the area of the geopark. National Geopark CiletuhPalabuhanratu already has a Geopark Management Bureau. This Bureau has the task to design and supervise programs carried out in the geopark, such as conservation, education, and community empowerment under the geopark motto. The unification of the CiletuhPalabuhanratu UGG is shown in Table 1.

Table 1. The Geo-bio and cultural aspect of CiletuhPalabuhanratu UGG.

\begin{tabular}{ll}
\hline Aspect & attractions \\
\hline Geo- & - Nature space \\
diversity & - Fossil and unique stone \\
& - Islands \\
& - Caves \\
& - Beach \\
\hline Bio-diversity & - National park \\
& - Suaka Margasatwa \\
& - Natural Conservation \\
& - Natural Park \\
& - Jungle Conservation \\
& - Turtle Conservation \\
& - Agriculture Plantation \\
& - Cultivation of Shrimp and Lobster Farms \\
& - Cultivation of eel sea \\
\hline Cultural & - Customary \\
& - Village \\
& - Archeologi site \\
& - Colonialism Building \\
& - Legend/Mith Batik Village
\end{tabular}

Sources: Ciletuh-Palabuhanratu Geopark Management Bureau, 2019. 
Figure 8 shows the geographical location of the Ciletuh-Palabuhanraturatu Geopark, which has been designated as National Geopark by the National Committee of Indonesian Geopark (KNGI) together with the Indonesian National Committee for UNESCO (KNIU) on December 22, 2015. Geopark has been extending and renames to become Geopark National CiletuhPalabuhanratu by the same committees on June 21, 2016, with the theme: "Subduction Fossil, Jampang Plateau, zone of magmatic movement".

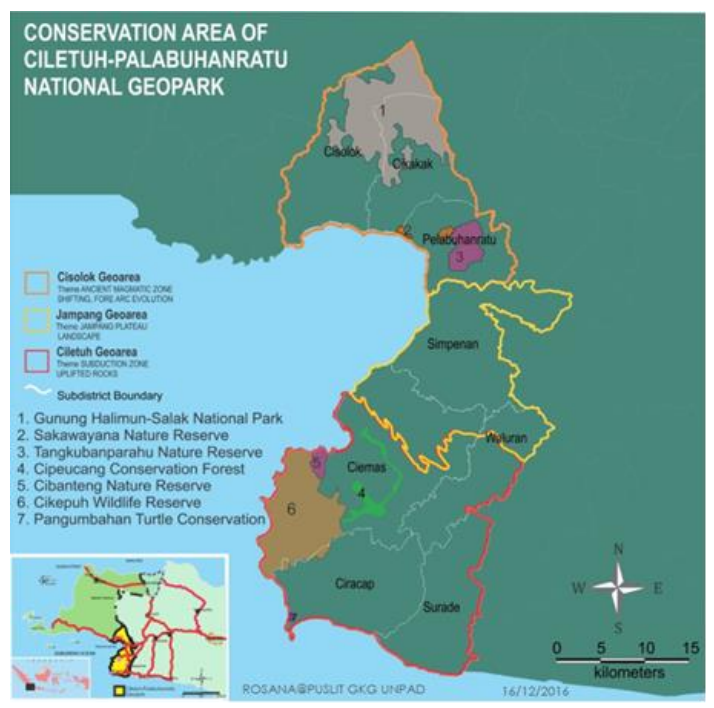

Figure 8. Conservation area of Ciletuh-Palabuhanratu National Geopark

Specifically, the role of the community has been shown in some activities by PAPSI Community (Paguyuban Alam Pakidulan Sukabumi). The community group has a concern about the management of the tourism aspect in Ciletuh-Palabuhanratu [18]. Together with Bio Farma, a pharmaceutical company, PAPSI start to develop Ciletuh-Palabuhanratu to become a UGG. There are five aspects that PAPSI and Biofarma doing to develop Ciletuh-Palabuhanratu UGG that is social, political, and economic, cultural, and environmental [18]. Furthermore, the development strategy that they use are:

- facilitating the community to fulfill the legal requirement and to managing the tourism attraction, including protecting environment

- promoting the local small-medium enterprises in selling their products

- sharing knowledge about conservation and sustainable development

- Providing the equipment and facilitation

\section{Toba Caldera (TC)}

The initiative of Toba Caldera (TC) to become a UNESCO Global Geopark (UGG) has already taken since 2012, in which TC become a member of Geopark Nasional. Since then, the TC focus on serious effort to become the next UGG in Indonesia. Following the government's reason in building Geopark, TC is built under the coordination of the local government that is the municipal of Samosir, one of seven municipal that surrounds TC (Fig. 9). The caldera itself meets the criteria of UGG as a geological heritage.

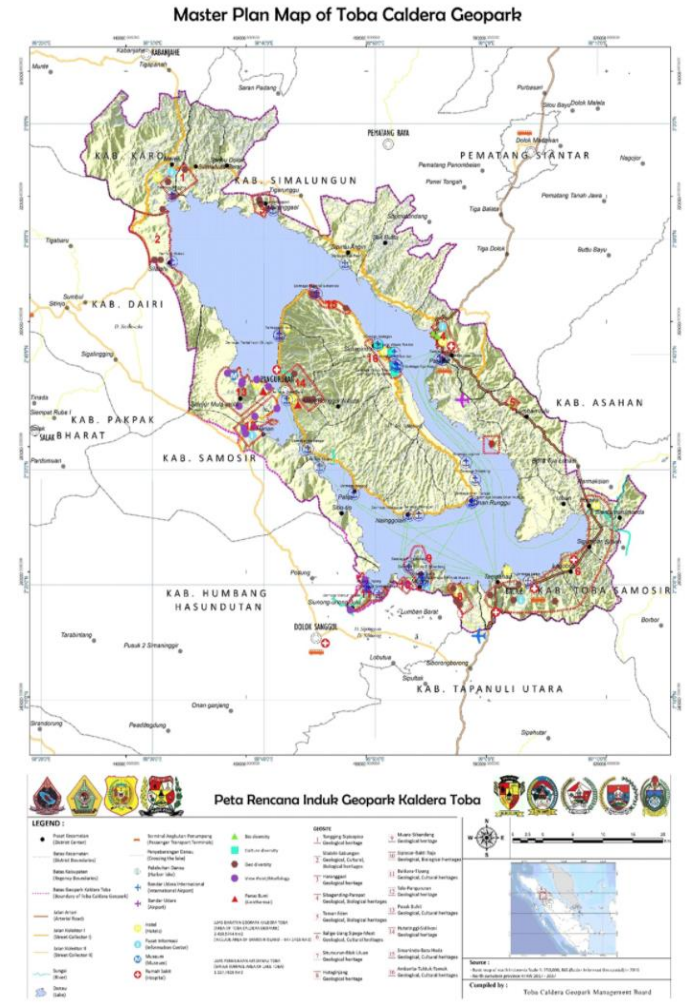

Figure 9. Geographical location of Toba Caldera

The process of TC development as UGG started with the identification of the potency of tourism based on the unification of the UGG, namely geo-diversity, bio-diversity, and culture (Fig. 10). The identification also focuses on the role of the community in the development process. The whole framework that we called a body of knowledge describes those stages (Fig. 10). As we can see from that figure, the center of the development is the unification of the UGG: Geo-diversity, Bio-diversity, and Cultural diversity. The foundation of the UGG development is the capacity building of the local community and government that will enhance the ten pillars as a support aspect.

The role of the community is essential since the geopark belongs to them. The involvement of the community is managed by the government tourism office. More specifically, in preparing 
local people to give excellent hospitality tourism, and leveraging the knowledge of community towards the importance of Geopark on their life. This process is called the soft skill building aspect. To facilitate this process, the management of TC UGG builds a website. Not only for the local people but the website also for the future tourist. Moreover, this website is one of the pre-requisite for becoming the UGG.

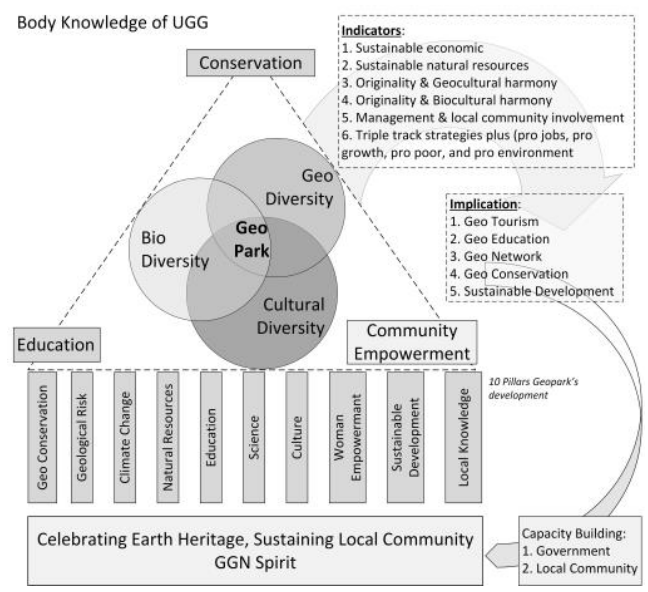

Figure 10. The body of knowledge of UGG (Source: CAREDS, 2016)

\section{Community-based Ecotourism Model for the Development of UGG}

Case studies result from Batur UGG, CiletuhPelabuhanratu UGG, and Toba Caldera, the bottom-up approach of the UNESCO direction in the development of the UGG is effective. The bottom-up approach is translated as an active role of the locals of the prospective area, including local government as an administrator, local entrepreneurs, local media, and indeed local community. The process may portray the goodness of fit of the community-based ecotourism model for the development of UGG. The effectiveness of the locals' involvement in achieving the mission of the UGG is proven by the case studies.

As we can see from all the UGG, the geological heritage has become an attraction of ecotourism. Table 2 below shows the offered attraction from the UGG that is related to ecotourism. The geo-sites are not only acted as an attraction of ecotourism but also the spirit of UGG that is promoting protection and sustainability.

Table 2. Geosites of UGG Batur, Ciletuh-Palabuhanratu, and Toba Caldera.

\begin{tabular}{|c|c|}
\hline UGG & Geo-sites \\
\hline Batur & $\begin{array}{l}\text { Two volcanic calderas and presents a complete volcanic landscape with: } \\
\text { - } \quad \text { caldera walls, } \\
\text { - } \quad \text { cones and craters, } \\
\text { - } \quad \text { geothermal phenomena (fumaroles, hot springs), } \\
\text { - } \quad \text { a lake, } \\
\text { - } \quad \text { lava flows, } \\
\text { - } \quad \text { pyroclastic flows, and tephra }\end{array}$ \\
\hline Toba Caldera & $\begin{array}{l}\text { Geo-area: } \\
\text { 1. Haranggaol (3 Geosites) } \\
\text { 2. Porsea (4 Geosites) } \\
\text { 3. Sibandang (4 Geosites) } \\
\text { 4. Samosir (4 Geosites) }\end{array}$ \\
\hline
\end{tabular}


The community-based ecotourism model is shown in Figure 11 . The case study of Batur UGG, Ciletuh-Pelabuhanratu UGG, and Toba Caldera comply with the Figure, which indicates that the development of UGG with communitybased should focus on two significant aspects, namely soft and hard aspect. These aspects are defined as,

a) Soft (knowledge, skill, and attitude). The soft aspects include the knowledge of tourism potency, the skill to manage the tourism business, and the attitude toward tourism services. This aspect is essential since that tourism-related to the service aspect.

b) Hard (infrastructure, media support arrangement) and is involving the four main actors: local community, local government, education institution, and business actors or business association. The hard aspects are including the local infrastructure, media arrangement, and many more.

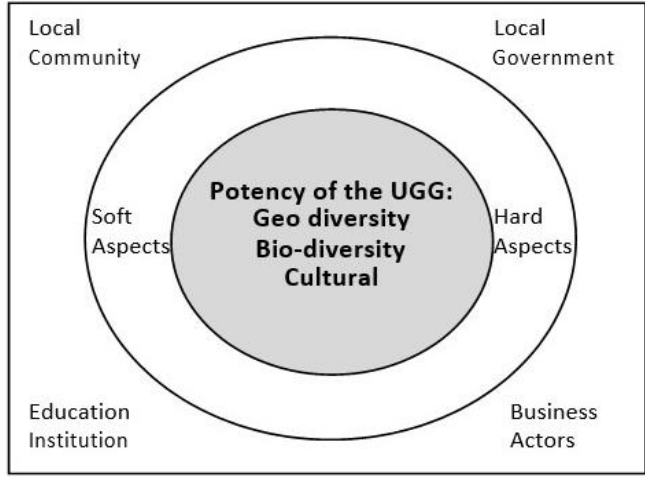

Figure 11. The community-based ecotourism model

Both elements are strategic support for the attraction itself, which is the unified geological heritage of UGG: geo-diversity, bio-diversity, and culture. Moreover, those aspects ran and managed by main actors in the tourism ecosystem, which are government, education institution, business, media, and of course, the community. Each actor in the CBE has a strategic contribution to developing, maintaining, and managing the ecotourism attraction. Table 3 describes the specific role of each actor.

The CBE is one of the implementations of community participation development. More specifically, the participation of the community in the development can be at the stage of the decision-making process, the planning process, the implementation process, and the evaluation and monitoring process. Tourism, especially ecotourism, belongs to the community because it is offering - the attraction: nature, cultural, and human-made objects, the services - are in the community itself. Therefore, the development of ecotourism should be community-centered at all stages of development $[3,12]$.

Table 3. The Role of Actors in Development of UGG process.

\begin{tabular}{|c|c|}
\hline Actor & Role in Development of UGG \\
\hline $\begin{array}{l}\text { Local } \\
\text { Government }\end{array}$ & $\begin{array}{l}\text { arrange and design the tourism } \\
\text { program and provide the budget }\end{array}$ \\
\hline Media & $\begin{array}{l}\text { arrange the communication strategy } \\
\text { about tourism potency as a marketing } \\
\text { promotion to attract many visitors. }\end{array}$ \\
\hline $\begin{array}{l}\text { Education } \\
\text { institution }\end{array}$ & $\begin{array}{l}\text { arrange and design a curriculum and } \\
\text { school program to enhance the } \\
\text { knowledge of tourism and specifically } \\
\text { geopark; also, the character and the } \\
\text { mindset building is the essential } \\
\text { program }\end{array}$ \\
\hline $\begin{array}{l}\text { Business/ } \\
\text { entrepreneur }\end{array}$ & $\begin{array}{l}\text { building the standard operating } \\
\text { procedure to pursue the quality } \\
\text { service; it is specifically for the } \\
\text { tourism business }\end{array}$ \\
\hline $\begin{array}{l}\text { Local } \\
\text { community }\end{array}$ & $\begin{array}{l}\text { Involve in a working group that works } \\
\text { for the development of the tourism } \\
\text { ecosystem }\end{array}$ \\
\hline
\end{tabular}

\section{CONCLUSION}

The research shows that (1) the community surrounding UGG Batur, Ciletuh-Palabuhanratu, and Toba Caldera, is the main actor in developing the UGG. More specifically, their contribution is through the group what we called Tourism Awareness Group (Pokdarwis). Besides the community, the other stakeholders also have a significant contribution; (2) the case of three UGG in this research meet with the implementation of community-based tourism. Also, the development of Unesco Global Geopark brings out ecotourism. Two of Geopark's unified geo-diversity and bio-diversity are strongly related to the theme of ecotourism. Also, with the spirit of UGG, that is education, protection, and sustainability. Meanwhile, the third pillar of UGG, culture, is related to community-based tourism.

\section{ACKNOWLEDGEMENT}

This research was proceeded with the involvement of some parties and resulting in effective collaborations. These include the management of UNESCO Global Geopark Batur Lake, the preparation team of Unesco Global Geopark Ciletuh-Palabuhanratu from UPI (Universitas Pendidikan Indonesia - Bandung), and the management of UNESCO Global Geopark Toba Caldera. 


\section{REFERENCES}

[1] Moswete, N. and B. Thapa. 2015. Factors that influence support for community-based ecotourism in the rural communities adjacent to the Kgalagadi Transfrontier Park, Botswana. Journal of Ecotourism 14(23), 243-263.

[2] Stronza, A. and J. Gordillo. 2008. Community views of ecotourism. Annals of tourism research 35(2), 448-468.

[3] Hakim, L., and M. Soemarno. 2017. Biodiversity conservation, community development and geotourism development in bromo-tengger-semeru-arjuno biosphere reserve. Geojournal of Tourism and Geosites 20(2), 220-230.

[4] Kiss, A. 2004. Is community-based ecotourism a good use of biodiversity conservation funds? Trends in ecology \& evolution 19(5), 232-237.

[5] Jones, S. 2005. Community-Based Ecotourism: The Significance of Social Capital. Annals of Tourism Research, 2005. 32(2), 303-324.

[6] Scheyvens, R. 1999. Ecotourism and the empowerment of local communities. Tourism management 20(2), 245-249.

[7] Sangpikul, A. 2017. Ecotourism impacts on the economy, society and environment of Thailand. Journal of Reviews on Global Economics 6, 302-312.

[8] Stone, M. and G. Wall. 2004. Ecotourism and community development: case studies from Hainan, China. Environmental management 33(1), 12-24.

[9] Rosana, M. F., H. Budiman, and O. Abdurahman. 2014. Geology, geotourism as definite factor for Geopark Ciletuh Indonesia. $6^{\text {th }}$ International UNESCO Conference on Global Geoparks, 80.

[10] Andriany, S.S., M.R. Fatimah, and A. Hardiyono. 2016. Geowisata Geopark Ciletuh: Geotrek Mengelilingi Keindahan Mega Amfiteater Ciletuh (The Magical of Ciletuh Amphitheater). Bulletin of Scientific Contribution: GEOLOGY 14(1), 75-88.

[11] Sekhar, N.U. 2003. Local people's attitudes towards conservation and wildlife tourism around Sariska Tiger Reserve, India. Journal of environmental Management 69(4), 339347.

[12] Hakim, L. 2017. Cultural landscape preservation and ecotourism development in Blambangan Biosphere Reserve, East
Java. In: Landscape Ecology for Sustainable Society, 341-358. Springer, Cham.

[13] Wood, M. 2002. Ecotourism: Principles, practices and policies for sustainability. UNEP.

[14] Su, M.M., G. Wall, and Z. Ma. 2014. Assessing Ecotourism from a Multistakeholder Perspective: Xingkai Lake National Nature Reserve, China. Environmental Management 54(5), 11901207.

[15] Cater, E. 1993. Ecotourism in the third world: problems for sustainable tourism development. Tourism Management 14(2), 85-90.

[16] Buckley, R. 1994. A framework for ecotourism. Annals of Tourism Research 21(3), 661-665.

[17] Yin, R.K. 2018. Case Study Research and Applications: Design and Methods. SAGE Publications. Singapore.

[18] Darsiharjo, D. 2016. Pengembangan Geopark Ciletuh berbasis partisipasi masyarakat sebagai kawasan geowisata di kabupaten Sukabumi. Jurnal Manajemen Resort dan Leisure 13(1), 55-60. 